\title{
Pengaturan Kecepatan Motor Induksi Tiga Fasa Menggunakan Metode Flux Vector Control Berbasis Self-Tuning PI
}

\author{
Ferry Arvianto dan Mochammad Rameli \\ Departemen Teknik Elektro, Fakultas Teknologi Elektro, Institut Teknologi Sepuluh Nopember (ITS) \\ e-mail: Rameli@ee.its.ac.id
}

\begin{abstract}
Abstrak-Motor induksi tiga fasa adalah penggerak elektrik yang banyak digunakan di dunia industri. Motor induksi juga memiliki kelemahan berupa sulitnya motor induksi dalam hal pengontrolan kecepatan dibandingkan dengan motor jenis DC. Motor induksi tiga fasa sulit dikontrol kecepatannya karena motor ini tidak linier dan parameter motornya dapat berubahubah yang disebabkan oleh suhu, saturasi magnetik, dan frekuensi. Penggunaan metode flux vector control dengan kontroler Self-Tuning PI dipilih untuk mendapatkan pengaturan kecepatan motor induksi yang baik. Metode flux vector control akan membuat motor induksi tiga fasa bisa dikontrol seperti motor dc penguatan terpisah. Sedangkan penggunaan SelfTuning Regulator digunakan untuk mengatasi perubahan parameter motor induksi. Sistem yang sudah dibuat disimulasikan di MATLAB dan hasil simulasi menunjukkan bahwa dengan menggunakan kontroler Self-Tuning PI lebih baik dibandingkan menggunakan kontroler PI konvensional, dimana kecepatan motor mampu mengikuti referensi kecepatan yang diberikan meskipun diberi pembebanan mekanik dan perubahan resistansi stator.
\end{abstract}

Kata Kunci-Motor induksi tiga fasa, flux vector control, SelfTuning Regulator, Self-Tuning PI.

\section{PENDAHULUAN}

M ESIN listrik, yang mengubah energi listrik menjadi energi gerak dan sebaliknya merupakan penggerak utama dalam sebuah sistem penggerak elektrik. Mesin ac ini sangat populer dikarenakan lebih kokoh, murah, keandalan kerja yang tinggi dan tidak perlu dilakukan perawatan yang terlalu sering dibandingkan mesin dc. Jenis motor ac yang banyak digunakan yaitu motor induksi dengan tipe rotor sangkar tupai (squirrel cage rotor). Namun motor induksi ini lebih dipilih untuk sistem pengerak yang membutuhkan kecepatan putar yang konstan. Sedangkan motor dc dipilih untuk sistem yang membutuhkan kecepatan yang bisa diatur. Hal itu terjadi karena kontrol kecepatan pada motor induksi jauh lebih sulit dibandingkan pada motor dc yang memiliki piranti kontrol yang lebih sederhana dan respon torsi yang cepat [1].

Sulitnya pengaturan kecepatan pada motor induksi dikarenakan motor jenis ini tidak linier. Penyebab motor tiga fasa ini tidak linier karena parameter pada motor induksi itu sendiri yang dapat berubah. Perubahan parameter tersebut dikarenakan beberapa hal antara lain suhu, saturasi magnetik, dan frekuensi [2]. Penambahan beban mekanik juga mampu mengubah parameter dari motor sehingga kecepatan motor akan berkurang dan tidak mencapai kecepatan yang diinginkan.

Berdasarkan kelemahan dari motor induksi tersebut maka dibutuhkan suatu cara untuk melakukan pengaturan kecepatan motor induksi agar dapat berputar sesuai dengan kecepatan yang diinginkan meskipun terjadi perubahan parameter dan terjadi penambahan beban. Metode yang dipilih adalah dengan menggunakan metode flux vector control (FOC) dimana dengan metode ini motor induksi akan mampu memiliki respon torsi dan fluks rotor yang sama dengan motor dc penguatan terpisah [2]. Untuk mengkompensasi perubahan parameter dan beban dari motor induksi terhadap perubahan kecepatan motor, kontroler yang dipilih adalah dengan menggunakan self-tuning regulator tipe PI agar tetap mampu mempertahankan kecepatan sesuai nilai kecepatan yang diinginkan.

\section{DASAR TEORI}

\section{A. Motor Induksi Tiga Fasa}

Sebuah motor induksi terdiri dari banyak bagian, stator dan rotor menjadi subsistem dasar dari mesin [3]. Rangkaian Stator merupakan bagian dari mesin yang tidak berputar dan terletak pada bagian luar. Terdiri dari tiga pasang kumparan, digabungkan secara bintang atau segitiga.

Gambar motor induksi tipe slip-ring dan tipe sangkar tupai dapat dilihat pada Gambar 1.

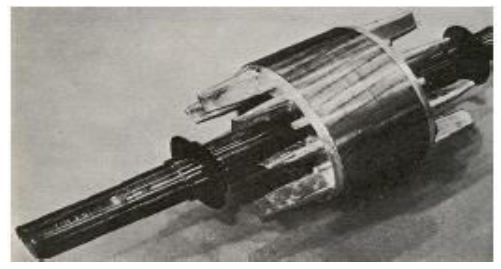

(a)

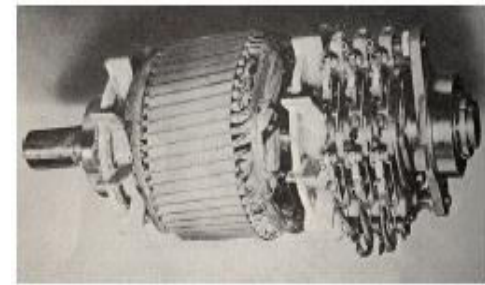

(b)

Gambar 1. (a) Rotor Tipe Sangkar Tupai (b) Rotor Tipe Slip-Ring. 
Prinsip kerja pada motor induksi erat kaitannya dengan Hukum Faraday dan Gaya Lorentz. Secara garis besar prinsip kerja dari motor induksi tiga fasa dapat dijelaskan dalam tahapan-tahapan di bawah ini:

a. Pada kumparan stator yang disuplai sumber tegangan tiga fasa akan timbul medan magnet. Adanya perubahan tegangan (sinusoidal) maka medan magnet akan berubah dan menimbulkan medan putar dengan kecepatan sinkron $\left(\mathrm{N}_{\mathrm{s}}\right)$. Besarnya nilai kecepatan sinkron dapat dirumuskan sebagai berikut

$$
N_{g}=\frac{60 . f}{p}
$$

b. Medan putar pada stator akan memotong konduktor yang terdapat pada sisi rotor, sehingga akan menimbulkan tegangan induksi (Hukum Faraday).

c. Tegangan induksi yang timbul pada konduktor yang dihubung singkat akan menghasilkan arus dan konduktor akan bekerja satu gaya mekanik (Gaya Lorentz

Tegangan terinduksi terjadi jika adanya perbedaan antara kecepatan angular dari medan putar stator $\left(N_{s}\right)$ dengan kecepatan putar rotor $\left(N_{r}\right)$. Perbedaan antara $N_{s}$ dan $N_{r}$ disebut dengan slip (S), dinyatakan dengan:

$$
s=\frac{\mathbb{N}}{\mathbb{N}_{s}}=\frac{\Delta \omega_{s}}{W_{s}}=\frac{\mathbb{N}_{s}-\mathbb{N}_{Y}}{\mathbb{N}_{s}}=\frac{\mathbb{W}_{s}-\mathbb{W}_{Y}}{W_{s}}
$$

\section{B. Permodelan Dinamik Motor Induksi Tiga Fasa}

Mesin tiga fasa dapat digambarkan dengan mesin dua fasa yang sebanding. Penggambaran motor induksi dalam dua fasa disimbolkan dalam sumbu d (direct) dan q (quadrature). Gambar kumparan tiga fasa dan dua fasa dapat dilihat pada Gambar 2.

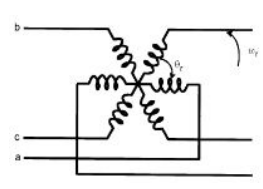

(a)

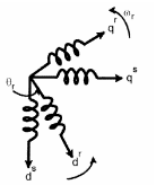

(b)
Gambar 2. (a) Efek Kopling pada Kumparan Stator dan Rotor Tiga Fasa (b) Kumparan Dua Fasa.

Transformasi Clarke dan park digunakan untuk mengubah koordinat motor induksi dari tiga fasa ke dalam koordinat dua fasa.

Transformasi Clarke ialah Transformasi dari koordinat tiga fasa ke koordinat stasioner dua fasa $(\alpha \beta)$.

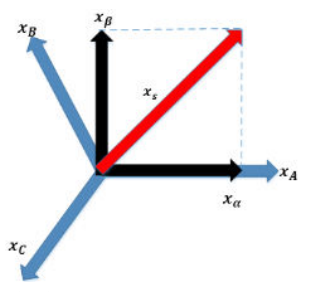

Gambar 3. Transformasi Clarke.

Persamaan 3 menunjukkan persamaan transformasi tiga fasa (abc) ke koordinat stasioner dua fasa $(\alpha \beta)$. Variabel X dapat berupa nilai tegangan, arus dan fluks. $\left[\begin{array}{l}x_{\alpha} \\ x_{\beta} \\ x_{0 g}\end{array}\right]=\frac{2}{a} \cdot\left[\begin{array}{ccc}1 & -\frac{1}{2} & -\frac{1}{2} \\ 0 & \frac{\sqrt{a}}{2} & -\frac{\sqrt{a}}{2} \\ \frac{1}{2} & \frac{1}{2} & \frac{1}{2}\end{array}\right]\left[\begin{array}{l}x_{a s} \\ x_{b s} \\ x_{c s}\end{array}\right]$

Transformasi Park digunakan untuk mengubah koordinat dua fasa stationer $(\alpha \beta)$ ke dalam koordinat synchronously rotating frame (dq) yang tetap pada rotor [1]. Gambar 4. menunjukkan gambar transformasi Park.

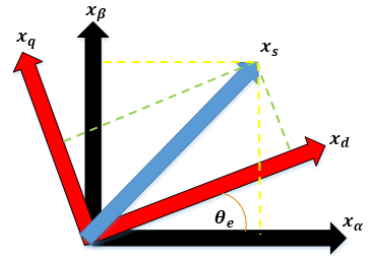

Gambar 4. Transformasi Park.

Persamaan 4 menunjukkan persamaan untuk mengubah koordinat dua fasa stationer $(\alpha \beta)$ ke dalam koordinat synchronously rotating frame $(\mathrm{dq})$.

$\left[\begin{array}{l}x_{d} \\ x_{q}\end{array}\right]=\left[\begin{array}{cc}\cos \theta_{e} & \sin \theta_{e} \\ -\sin \theta_{\theta} & \cos \theta_{\theta}\end{array}\right]\left[\begin{array}{l}x_{\alpha} \\ x_{\beta}\end{array}\right]$

Analisis dari rangkaian ekivalen meliputi tegangan stator dan rotor, flux linkage, dan torsi dari motor induksi. Persamaan 5 menyatakan persamaan untuk tegangan stator dan rotor.

$$
\begin{aligned}
& V_{d s}=R_{g} i_{d s}+\frac{d \lambda_{d s}}{d t}-\omega_{g} \lambda_{q s} \\
& V_{d r}=0=R_{y} i_{d r}+\frac{d \lambda_{d r}}{d t}-\left(\omega_{\theta}-\omega_{r}\right) \lambda_{q r} \\
& V_{q s}=R_{g} i_{q s}+\frac{d \lambda_{q s}}{d t}+\omega_{\theta} \lambda_{d s} \\
& V_{q r}=0=R_{g} i_{q r}+\frac{d \lambda_{q r}}{d t}+\left(\omega_{\theta}-\omega_{r}\right) \lambda_{d r}
\end{aligned}
$$

Lalu untuk persamaan flux linkage ditunjukkan pada persamaan 6.

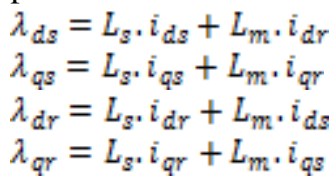

Kemudian persamaan 6 disubstitusikan kepersamaan 5 sehingga didapatkan persamaan 7 .

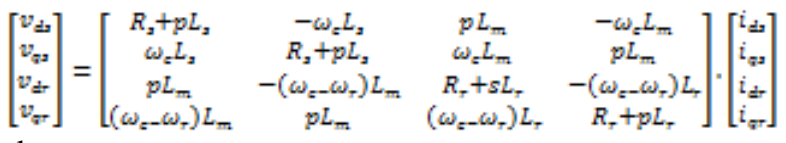

dengan,

$$
\begin{aligned}
& p=\frac{d}{d t} \\
& L_{g}=L_{i s}+L_{m} \\
& L_{y}=L_{l p}+L_{m}
\end{aligned}
$$

\section{Metode Vector Control}

Salah satu pengendalian motor induksi adalah vector control. Vector Control atau disebut juga Field Oriented Control (FOC) merupakan metode pengaturan medan pada motor ac, di mana sistem coupled diubah menjadi sistem decoupled. Dengan sistem ini sistem ini arus penguatan dan 
arus beban motor dapat dikontrol secara terpisah, dengan demikian torsi dan fluks juga dapat diatur secara terpisah.

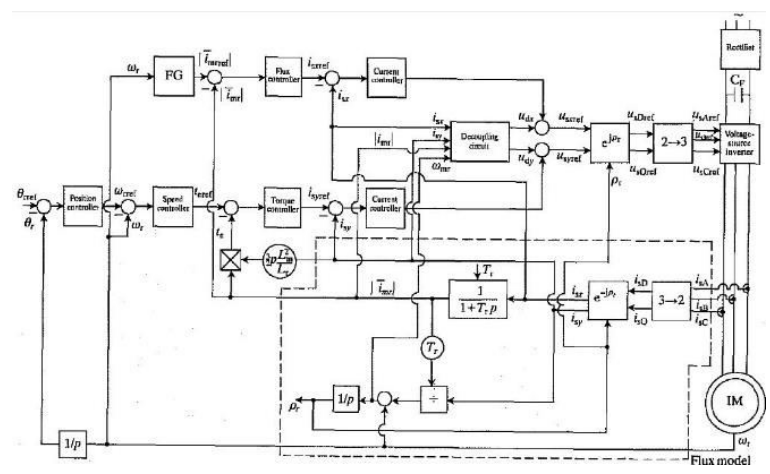

Gambar 5. Diagram Blok Indirect Vector Control

Untuk pengaturan secara terpisah (decoupling control), diinginkan $\lambda_{q r}=0$.

$\lambda_{r}=\frac{L_{m}}{T_{r} S+1} i_{d s}$

atau jika fluks $\hat{\lambda}_{r}=$ konstan maka,

$\lambda_{r}=L_{m} i_{d s}$

Nilai kecepatan slip $\left(\omega_{\mathrm{s}}\right)$

$\omega_{s l}=\frac{L_{m} R_{r}}{\hat{\lambda}_{r} L_{r}}$

\section{Kontroler PID}

Kontroler PID merupakan kontroler yang memanfaatkan umpan balik untuk memperbaiki kinerja sistem atau proses. Kontroler ini menghitung nilai kesalahan (error) yang merupakan perbedaan antara nilai acuan (setpoint) dan keluaran yang terukur sensor. Gambar 6 menunjukkan diagram blok kontroler PID [3].

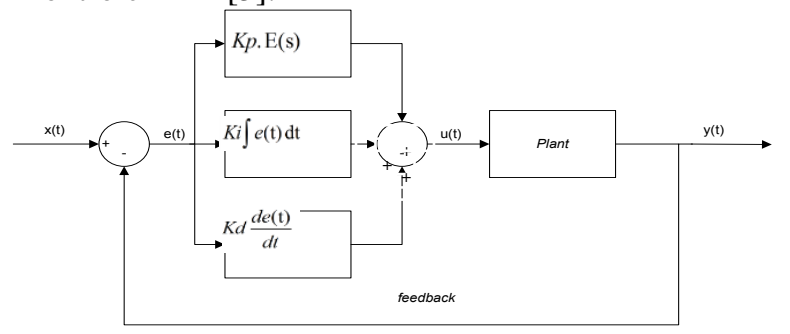

Gambar 6. Kontroler PID.

Dari diagram blok pada Gambar 6. dapat ditulis dalam persamaan Laplace sebagai berikut:

$\mathrm{U}(\mathrm{s})=\mathrm{Kp} \cdot\left(\mathrm{E}(\mathrm{s})+\frac{\mathrm{Ki}}{\mathrm{s}} \mathrm{E}(\mathrm{s})+\mathrm{Kds} \cdot \mathrm{E}(\mathrm{s})\right)$

\section{E. Metode Self-Tuning Regulator}

Dengan metode ini, setiap perubahan yang terjadi pada plant akan diestimasikan, dimana variabel proses hasil estimasi tersebut akan digunakan untuk merancang kontroler baru untuk update parameter PI. Prinsip kerja metode self-tuning regulator secara rinci dapat dicek pada diagram blok seperti pada Gambar 7.

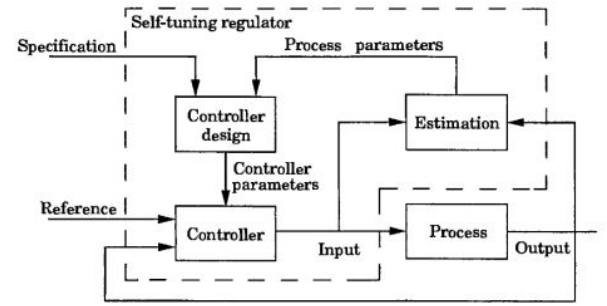

Gambar 7. Diagram blok self-tuning regulator

Metode self-tuning regulator terdiri dari 2 loop. Loop pertama merupakan sistem closed loop pada umumnya yang meliputi kontroler, plant dan sinyal feedback, sedangkan loop lainnya melibatkan proses estimasi, perancangan kontroler baru dan penalaan parameter kontroler.

\section{PERANCANGAN SISTEM}

\section{A. Desain Sistem Secara Umum}

Secara umum, desain sistem yang akan dirancang ditunjukkan pada Gambar 8.

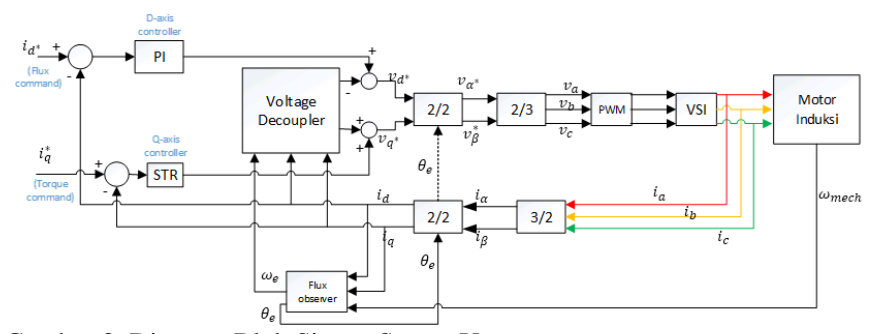

Gambar 8. Diagram Blok Sistem Secara Umum.

\section{B. Permodelan Motor Induksi Tiga Fasa}

Parameter motor induksi tiga fasa yang digunakan pada Tugas Akhir ini ditunjukkan pada Tabel 1.

Tabel 1.

Parameter Motor Induksi Tiga Fasa

\begin{tabular}{|c|c|c|c|}
\hline No. & Nama & Satuan & Nilai \\
\hline 1 & $\begin{array}{l}\text { Tegangan Sumber }\left(\mathrm{V}_{\text {line-to- }}\right. \\
\text { line }\end{array}$ & VAC & 600 \\
\hline 2 & Frekuensi $(\mathrm{F})$ & $\mathrm{Hz}$ & 60 \\
\hline 3 & Tahanan Stator $\left(\mathrm{R}_{\mathrm{s}}\right)$ & Ohm & 4,85 \\
\hline 4 & Tahanan Rotor $\left(\mathrm{R}_{\mathrm{r}}\right)$ & Ohm & 3,805 \\
\hline 5 & Induktansi Stator $\left(\mathrm{L}_{\mathrm{s}}\right)$ & $\mathrm{mH}$ & 0,274 \\
\hline 6 & Induktansi Rotor $\left(\mathrm{L}_{\mathrm{r}}\right)$ & $\mathrm{mH}$ & 0,274 \\
\hline 7 & Induktansi Mutual $\left(\mathrm{L}_{\mathrm{m}}\right)$ & $\mathrm{mH}$ & 0,258 \\
\hline 8 & Jumlah Pole & & 4 \\
\hline 9 & Inersia Rotor $\left(\mathrm{J}_{\mathrm{r}}\right)$ & $\mathrm{Kg} \cdot \mathrm{m}^{2}$ & 0,031 \\
\hline 10 & Tenaga Motor & KW & 1.5 \\
\hline
\end{tabular}

Dari model dinamik d-q berbentuk matriks sesuai dengan persamaan 7 akan didapatkan persamaan berikut.

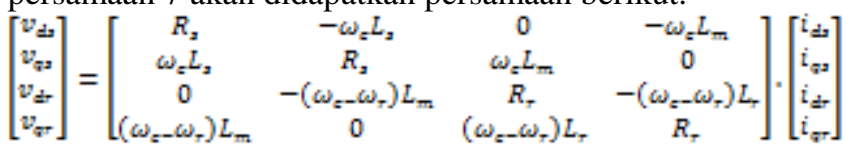




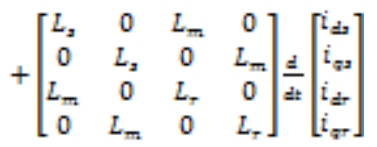

Untuk mendapatkan bentuk persamaan differensial $\left(\frac{d i}{d t}\right)$ maka perlu dilakukan permisalan sebagai berikut.

$$
\begin{aligned}
A & =\left[\begin{array}{cccc}
R_{z} & -\omega_{s} L_{s} & 0 & -\omega_{s} L_{m} \\
\omega_{s} L_{s} & R_{s} & \omega_{s} L_{m} & 0 \\
0 & -\left(\omega_{s-}-\omega_{r}\right) L_{m} & R_{r} & -\left(\omega_{s}-\omega_{r}\right) L_{r} \\
\left(\omega_{s}-\omega_{r}\right) L_{m} & 0 & \left(\omega_{s}-\omega_{r}\right) L_{r} & R_{r}
\end{array}\right] \\
B & =\left[\begin{array}{cccc}
L_{s} & 0 & L_{m} & 0 \\
0 & L_{s} & 0 & L_{m} \\
L_{m} & 0 & L_{r} & 0 \\
0 & L_{m} & 0 & L_{r}
\end{array}\right]
\end{aligned}
$$

$i=\left[i_{d g} i_{q g} i_{d v} i_{q V}\right]^{T}$

$v=\left[v_{d s} v_{q s} v_{d r} v_{q V}\right]^{Y}$

Dengan menggunakan persamaan 14-16 maka persamaan 13 bisa diubah menjadi bentuk lebih sederhana seperti pada persamaan 17 .

$$
\begin{aligned}
& v=A_{\cdot} i+B \cdot \frac{d i}{d t} \\
& \frac{d i}{d t}=B^{-1} \cdot v-B^{-1} A \cdot i
\end{aligned}
$$

Dimana persamaan torsi sebagai berikut.

$T_{e}=\frac{a}{2} \frac{P}{2} L_{m}\left(i_{q g} \cdot i_{d y}-i_{d g} i_{q V}\right)$

Setelah didapatkan semua persamaan state dari arus dan torsi maka dibuat program motor induksi ini ke dalam embedded matlab function.

Nilai kecepatan mekanik motor $\left(\omega_{m}\right)$ dan kecepatan rotor $\left(\omega_{y}\right)$ sesuai dengan persamaan berikut.

- $T_{e}=T_{L}+j \cdot \frac{d \omega_{m}}{d t}$

$$
\begin{gathered}
\omega_{m}=\int \frac{\left(T_{q}-T_{L}\right)}{J} \\
-T_{e}=T_{L}+\frac{2}{\mathrm{p}} \cdot J \cdot \frac{d \omega_{r}}{d t} \\
\omega_{y}=\int \frac{T_{q}-T_{L}}{J} \cdot \frac{p}{2}
\end{gathered}
$$

Dari persamaan 20 dan 21 akan dibuat kedalam bentuk blok diagram kedalam Simulink bersama dengan permodelan motor induksi sehingga didapatkan blok diagram seperti pada Gambar 9.

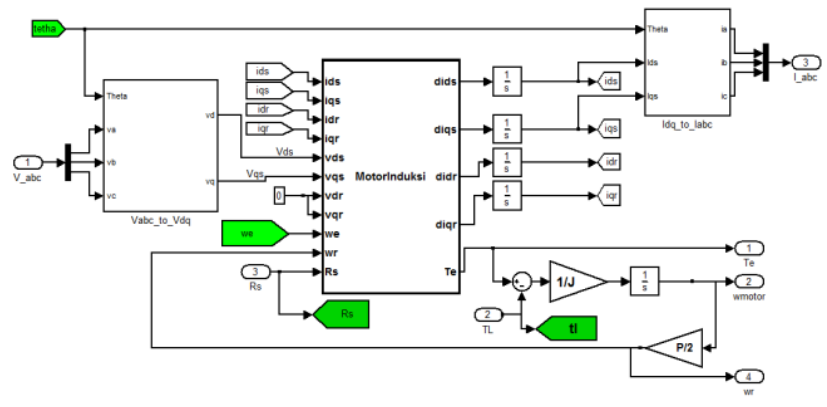

Gambar 9. Permodelan Motor Induksi Tiga Fasa

\section{Transformasi Tiga Fasa ke Dua Fasa}

Pada bagian blok untuk transformasi tiga fasa menjadi dua fasa menggunakan persamaan transformasi Clarke sesuai persamaan 3 untuk mengubah bidang tiga fasa menjadi frame stasioner dua fasa $(\alpha \beta)$. Lalu dari frame stasioner dua fasa $(\alpha \beta)$ akan diubah ke frame rotasi dua fasa (dq) dengan menggunakan persamaan transformasi park sesuai persamaan 5 sesuai dengan persamaan yang disebutkan maka bentuk simulasi di Simulink seperti pada Gambar 10.

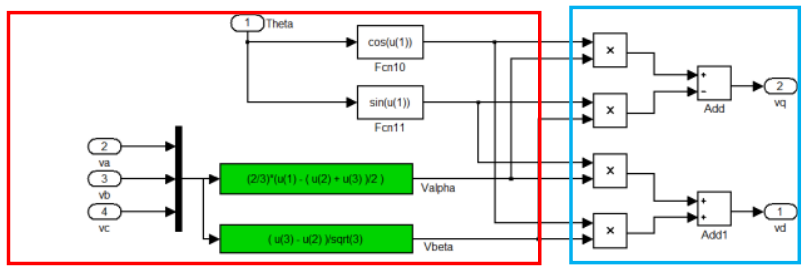

Gambar 10. Transformasi Tegangan Tiga Fasa ke Tegangan dq.

\section{Perancangan Metode Vector Control}

Pada metode indirect vector control terdiri dari beberapa bagian antara lain transformasi vector, perhitungan nilai tetha $\left(\theta_{\theta}\right)$, perhitungan nilai $i_{d s}^{*}$, perhitungan nilai $i_{q s}^{*}$, dan penggunaan hysteresis band current control yang digunakan untuk menghasilkan sinyal PWM.

1) Perhitungan Nilai tetha $\left(\theta_{e}\right)$

Nilai ini akan digunakan pada transformasi park dan transformasi invers park. Untuk persamaan yang digunakan seperti di bawah ini.

$\omega_{s I}=\frac{\left(\tilde{i}_{q} L_{m}\right]}{\lambda_{d r}}\left(\frac{R_{r}}{L_{r}}\right)=\frac{\left(\tilde{i}_{q} L_{m}\right)}{\tau_{r} \lambda_{d r}}$

$\omega_{e}=\omega_{g i}+\omega_{\text {mech }}$

$\theta_{e}=\int \omega_{e} d t$

Dari persamaan diatas kemudian diubah kedalam blok diagram perhitungan tetha yang ditunjukkan oleh Gambar 11.

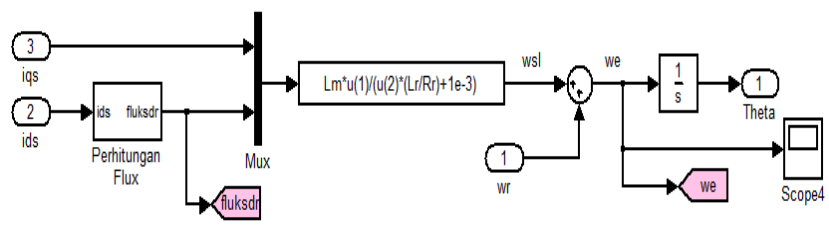

Gambar 11. Perhitungan Nilai Tetha $\left(\theta_{2}\right)$ dan $\omega_{z}$

2) Perhitungan Nilai Arus Quadrature ( $\left.\mathbf{I}_{\mathrm{q} s}^{*}\right)$

Sinyal kontrol menghasilkan nilai torsi $\left(T_{e}^{*}\right)$ yang kemudian akan diubah menjadi nilai $\mathbf{I}_{\mathrm{qs}}^{*}$. Nilai $\mathbf{I}_{\mathrm{qs}}^{*}$ didapatkan dari persamaan dibawah ini.

$$
\begin{aligned}
& \text { - } T_{e}=\frac{3}{2} \times \frac{p}{2} \cdot \frac{L_{m}}{L_{Y}} \cdot \lambda_{d r} \cdot i_{q s} \\
& i_{q s}^{*}=\frac{2}{a} \times \frac{2}{p} \times \frac{L_{r}}{L_{m}} \times \frac{T_{Q}}{d_{d i r}}=\frac{4}{a p} \times \frac{L_{r}}{L_{m}} \times \frac{T_{Q}}{d_{d r}}
\end{aligned}
$$

Mengacu pada persamaan 25, maka program pada Simulink akan seperti pada Gambar 12.

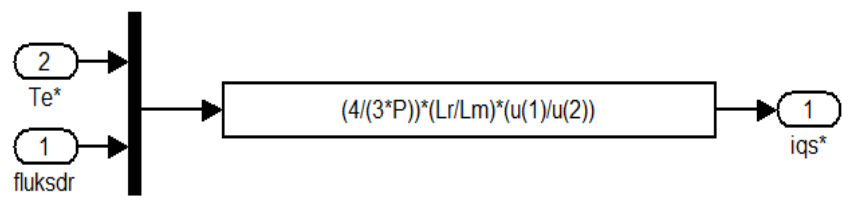

Gambar 12. Perhitungan Nilai $\check{i}_{q}$, 


\section{3) Perhitungan Nilai Arus Direct $\left(\mathbf{I}_{\mathbf{d s}}^{*}\right)$}

Setelah mendapatkan nilai $\mathbf{I}_{\mathrm{q} s}^{*}$, maka nilai yang sekarang dibutuhkan adalah nilai $\mathbf{I}_{\mathrm{ds}}^{*}$. Nilai $\mathbf{I}_{\mathrm{ds}}^{*}$ didapatkan berdasarkan rumus dari $\lambda_{d r}$ pada persamaan 6 karena $\lambda_{d r}$ bernilai konstan maka persamaan $\mathbf{I}_{\mathrm{ds}}^{*}$ akan sebagai berikut.

- $\lambda_{d r}=L_{m}, i_{d g}$

- $i_{d s}^{*}=\frac{\lambda_{d r}}{L_{m}}$

Mengacu pada persamaan 26, maka program pada Simulink akan seperti pada Gambar 13.

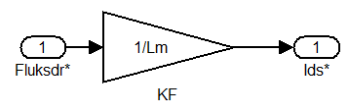

Gambar 13. Perhitungan Nilai $i_{\underline{A}}^{*}$

\section{4) Perancangan Hysterisis-Band Current Control PWM}

Nilai referensi arus tiga fasa $\left(\mathbf{i}_{\mathbf{z}}^{*}, \mathbf{i}_{\mathbf{b}}^{*}, \mathbf{i}_{c}^{*}\right)$ yang sudah didapatkan akan dibandingkan dengan nilai arus aktual $\left(\boldsymbol{i}_{a}, \boldsymbol{i}_{b}, \boldsymbol{i}_{c}\right)$ untuk menentukan sinyal PWM yang dibutuhkan inverter.Untuk blok diagram program hysterisis-band current control PWM ditunjukkan pada Gambar 14.

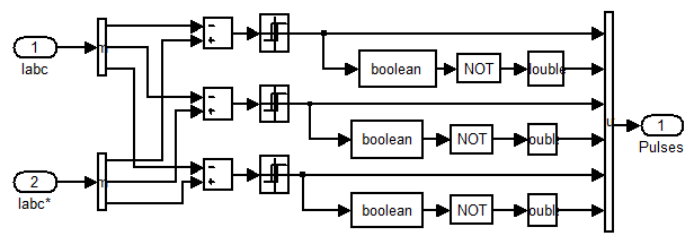

Gambar 14. Blok Diagram Hysterisis-Band Current Control PWM

\section{E. Perancangan Metode Self-Tuning Regulator}

Metode self-tuning regulator mampu merubah parameter kontroler dengan cara menyesuaikan nilainya dengan parameter dari plant yang berubah-ubahPada loop pertama dilakukan estimasi parameter menggunakan sinyal keluaran dari kontroler dan sinyal keluaran dari sistem untuk menentukan nilai parameter secara online saat sistem berjalan seperti pada Gambar 15.

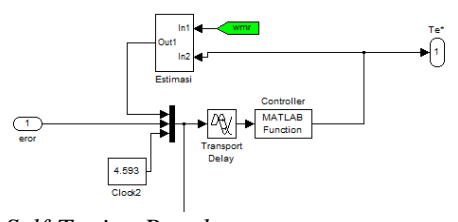

Gambar 15. Loop Self-Tuning Regulator.

Tahapan untuk mendapatkan kontroler antara lain menentukan nilai $\boldsymbol{\tau}$ dan $\boldsymbol{K}$ secara peritungan offline lalu mengupdate nilai kontroler PI yang sudah di ubah kebentuk persamaan beda. Untuk nilai $\boldsymbol{\tau}$ dan $\boldsymbol{K}$ setelah melakukan perhitungan didapatkan sebagai berikut.

$\tau=\frac{T g}{2} \cdot \frac{1-a_{1}}{a_{1}+1}$

$K=(2 \tau+T s) \cdot \frac{b_{0}}{T s}$ $(\theta)$.

\section{PENGUJIAN DAN ANALISIS DATA}

\section{A. Pengujian dan Analisa Respon Asli Motor Induksi Tiga} Fasa

Respon kecepatan motor yang didapatkan ditunjukkan pada Gambar 16.

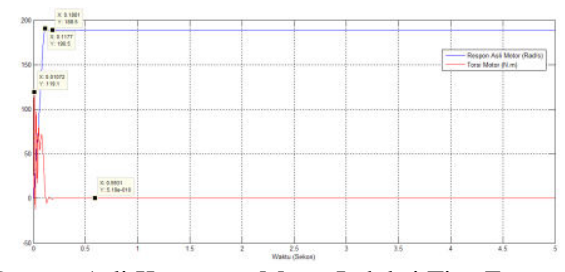

Gambar 16. Respon Asli Kecepatan Motor Induksi Tiga Fasa

Berdasarkan hasil pengujian yang ditunjukkan Gambar 16, respon kecepatan mencapai steady state pada $\mathrm{t}=0,1881$ detik dengan kecepatan sebesar $188.5 \mathrm{rad} / \mathrm{s}$ Torsi motor saat starting terjadi lonjakan dimana mencapai titik tertinggi sebesar 119 N.m saat $\mathrm{t}=0.0172$ detik namun saat kecepatan motor sudah mencapai kecepatan steady, torsi yang dihasilkan motor bernilai di sekitar 0 N.m.

\section{B. Pengujian dan Analisa Metode Vector Control dengan Kontroler PI}

Pada Tugas Akhir ini, pengujian dilakukan dengan cara tanpa diberi beban ,pemberian beban, dan perubahan Rs.

1) Respon Kecepatan Motor Tanpa Beban

Hasil yang didapatkan ditunjukkan pada Gambar 17.

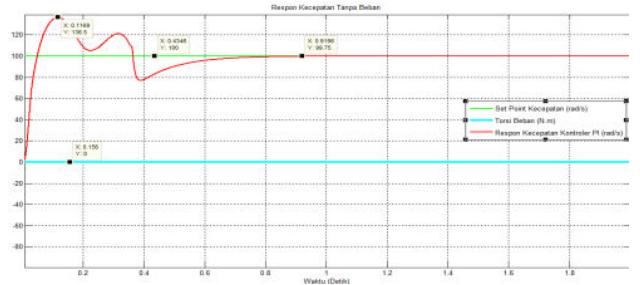

Gambar 17. Respon Kecepatan Tanpa Beban untuk Kontroler PI.

Dari Gambar 17 diketahui bahwa motor mencapai kecepatan steady state saat $\mathrm{t}=0.9011$ detik dengan kecepatan $99.92 \mathrm{rad} / \mathrm{s}$ dan memiliki overshoot hingga $132 \mathrm{rad} / \mathrm{s}$.

2) Respon Kecepatan Motor dengan Beban Maksimum

Hasil yang didapatkan ditunjukkan pada Gambar 18.

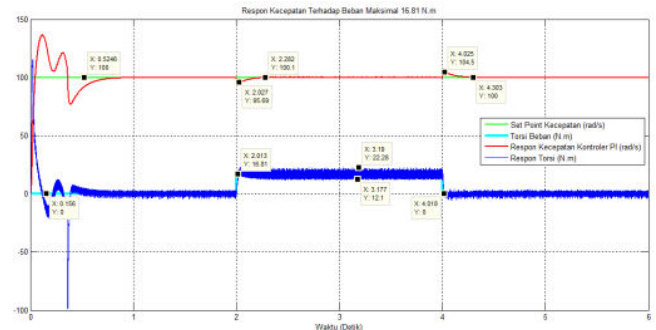

Gambar 18. Respon Kecepatan Motor dengan Beban Maksimum

Dari Gambar 18 dilakukan pengujian dengan memberikan beban maksimum sebesar 16.8125 N.m pada saat detik kedua. Kecepatan dari motor turun sesaat sehingga menjadi 95.69 $\mathrm{rad} / \mathrm{s}$ lalu kemudian kembali ke kecepatan awal pada 0.282 detik selanjutnya. 
3) Respon Kecepatan Motor dengan Perubahan Resistansi Stator

Hasil yang didapatkan seperti pada Gambar 19.

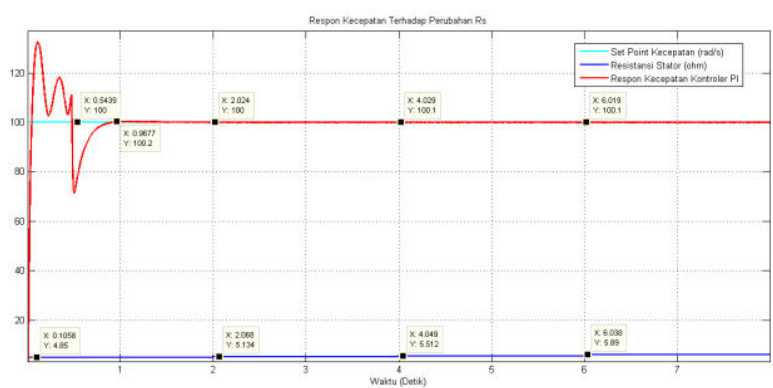

Gambar 19. Respon Kecepatan dengan Perubahan Rs.

Dari Gambar 19 dapat diketahui jika saat dilakukan perubahan resistansi stator pada setiap dua detik, tidak terjadi perubahan kecepatan pada sistem.

C. Pengujian dan Analisa Metode Vector Control dengan Kontroler Self-Tuning PI

Pada Tugas Akhir ini, pengujian dilakukan dengan cara tanpa diberi beban, pemberian beban, dan perubahan Rs.

1) Respon Kecepatan Motor Tanpa beban

Hasil yang didapatkan ditunjukkan pada Gambar 20.

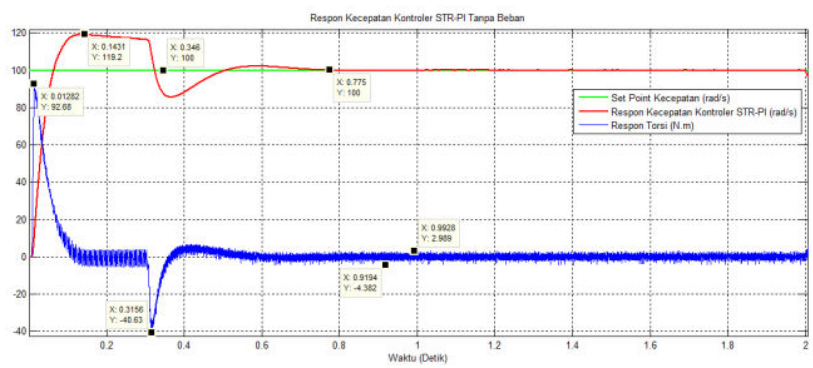

Gambar 20. Respon Kecepatan Motor Tanpa Beban.

Dari Gambar 20 diketahui bahwa motor mencapai kecepatan steady state saat $\mathrm{t}=0.775$ detik dengan kecepatan $100 \mathrm{rad} / \mathrm{s}$ dan memiliki overshoot hingga $119.2 \mathrm{rad} / \mathrm{s}$.

2) Respon Kecepatan Motor dengan Beban Maksimal

Hasil yang didapatkan seperti pada Gambar 21.

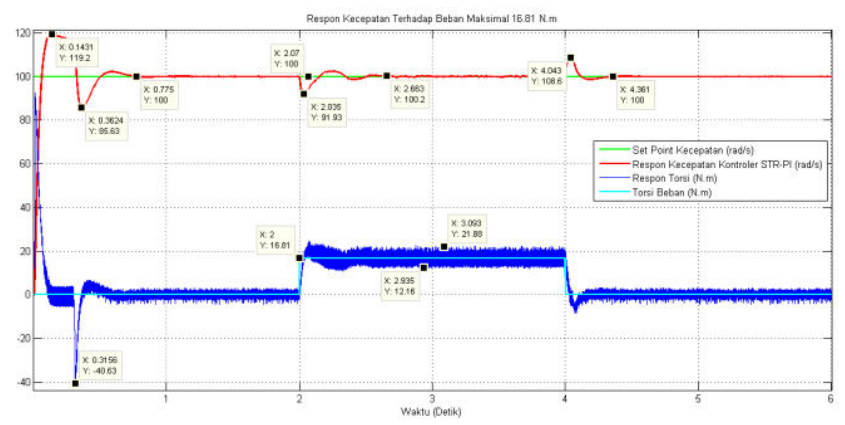

Gambar 21. Respon Kecepatan dengan Beban Maksimal.
Dari Gambar 21 dilakukan pengujian dengan memberikan beban maksimum sebesar 16.8125 N.m pada saat detik kedua. Kecepatan dari motor turun sesaat sehingga menjadi 91.93 $\mathrm{rad} / \mathrm{s}$ lalu kemudian kembali ke kecepatan awal pada 0.663 detik selanjutnya.

3) Respon Kecepatan Motor dengan Perubahan Resistansi Stator

Hasil yang didapatkan seperti pada Gambar 22.

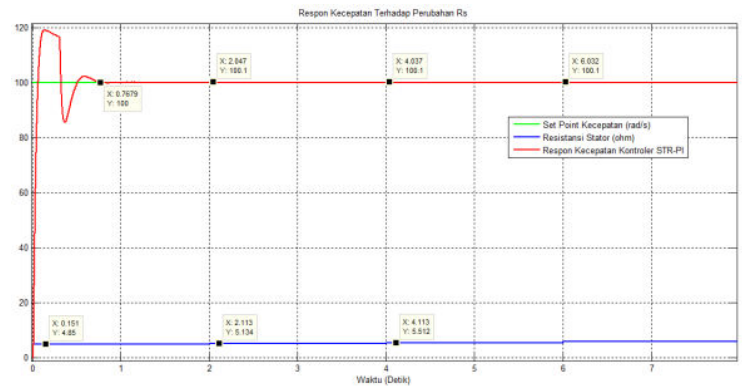

Gambar 22. Respon Kecepatan dengan Perubahan Rs.

Dari Gambar 22 dapat diketahui jika saat dilakukan perubahan resistansi stator pada setiap dua detik, tidak terjadi perubahan kecepatan pada sistem.

\section{KESIMPULAN/RINGKASAN}

Berdasarkan hasil simulasi dari sistem kontrol Self-Tuning PI dalam pengaturan kecepatan motor induksi tiga fasa dapat diambil kesimpulan sebagai berikut:

1. Pengaturan kecepatan motor induksi menggunakan kontroler Self-tuning PI untuk arus quadrature mampu mengurangi overshoot kecepatan motor dari $132.8 \mathrm{rad} / \mathrm{s}$ menjadi $119.2 \mathrm{rad} / \mathrm{s}$.

2. Respon torsi dengan menggunakan kontroler Self-Tuning PI menghasilkan Overshoot yang lebih rendah dibandingkan dengan menggunakan kontroler PI konvensional.

3. Penggunaan Kontroler Self-Tuning PI untuk arus quadrature mampu mengembalikan kecepatan motor sesuai set-point meskipun terjadi perubahan parameter dikarenakan penambahan beban mekanik

Perubahan nilai resistansi stator untuk batas suhu lingkungan kerja yang diijinkan tidak berpengaruh Pada Respon Kecepatan Motor Induksi.

\section{DAFTAR PUSTAKA}

B. . Bose, Modern Power Electronics and AC Drives. Prentice Hal, Inc, 2002.

[2] D. M. W. Telford and B. W. W. Dunnigan, A Self-Tuning Regulator for Induction Machine Vector Control. .

[3] K. Astrom and Hagglund, "Advanced PID Control Instrument Society of America," North Carolina, 1995. 